\section{Cell Size and Pretransplant Nutritional Conditioning Influence Growth and Yield of Transplanted 'J ubilee' Watermelon}

\author{
Charles J. Graham, ${ }^{1}$ \\ James T. Payne, ${ }^{2}$ and \\ Eric J. M olnar ${ }^{2}$
}

Additional indeX wORds. Citrullus lanatus, fertility, production

Summary. Increasing cell volume or pretransplant nutrient conditioning (PNC) reduced the time to flowering for staminate and pistillate flowers in watermelon [Citrulluslanatus

(Thunb.) M atsum. \& N akai]. L arger cell volumes increased the number of early harvested watermelons and average watermelon weight in two of three studies. Similarly, larger cell volume increased the early and total yield per area of watermelons harvested in 1995 and 1998, but not in 1997. E ffect of transplant cell volume on soluble solids varied seasonally. PN C increased the number of melons and the yield per area harvested early in 1995 and soluble solids in early harvested fruit in 1997, but had no significant effect on total 'Jubilee' watermelon size or total production in Louisiana for 1995, 1997, or 1998. PN C offers the transplant grower little advantage, while increasing transplant cell size provides a grower with a better opportunity to produce increased early and total yields.

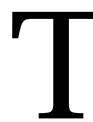

ransplanting is the most efficient method to establish a watermelon crop because of the increasing costs of hybrid dip-

Calhoun Research Station, P.O. Box 539, $321 \mathrm{H}$ ighway 80 East, Louisiana State U niversity Agricultural Center, C alhoun, LA 71225.

${ }^{1}$ Assistant professor.

${ }^{2}$ Research associate. loid and triploid seed. Transplants can also increase earliness (I vanhoff et al., 1960; N ettles, 1963; N orton, 1968) and reducefield establishment costs of direct seeding in the field with expensive hybrid seed (I vanhoff et al., 1960; Giacchetti, 1997). Cell volumeof transplant flats and nutrition during transplant growth can affect subsequent transplant growth and development, and yield in the field.

M ulticell seedling flats are convenient for both propagating and handling vegetable transplants. Plants grown in small cells are less expensive to produce than those in large cells because less greenhouse space and media are required ( $D$ ufault and $W a-$ ters, 1985; Weston and Zandstra, 1986). Small cells also permit the handling of fewer trays for transport and transplanting. Smaller cell volumes, however, often produce smaller transplants that grow less vigorously (D ufault and Waters, 1985; M arsh and Paul, 1988; Weston and Z andstra, 1986) and sometimes produce lower yields than comparable plantings established from larger transplants produced by large cell volumes ( $M$ arsh and Paul, 1988; V avrina, 1997; W eston and Zandstra, 1986).

Pretransplant nutritional conditioning (PNC) has been shown to influence transplant quality, seedling establishment, and yield for several crops (Adler et al., 1984; M elton and D ufault, 1991; Schultheisand D ufault, 1994; Weston and Zandstra, 1989). Early harvests were increased by high PNC vs. Iow PNC for muskmelon (Cucumis melo L.) (Dufault, 1986) and tomato (Lycopersicon esculentum M ill.) (Weston and Z andstra, 1989), but total yields of both crops were unaffected.

Research is needed to better understand the influence of cell volume and nutrition on watermelon transplant size, plant develo pment, and production in the field in order to determine the most economic production practices. The primary objective of this study was to compare the effect of flat cell volume and PNC on early and cumulative production and quality of transplanted 'J ubilee' watermelons.

\section{Materials and methods}

On 7 Apr. 1995, 22 Apr. 1997, and 9 Apr. 1998, 'J ubilee' watermelon seeds were planted 0.5 inch deep in a peat-vermiculitemix ( $M$ etro-M ix366,
Scotts-Sierra, M arysville, 0 hio) placed in 18-, 32-, 72-, and 128-cell TOD D planter flats (Speedling, I nc., Sun C ity, Fla). T wo seeds were planted per cell and thinned to one plant per cell after germination. The $4 \times 4$ factorial experiment consisted of four cell volumes [1.9 (30.7), 4.0 (65.5), 9.0 (147.5), and 21.3 inch $^{3}\left(349.6 \mathrm{~cm}^{3}\right)$ ] and four fertilizer rates $(0,25 \%, 50 \%$ and full strength $\mathrm{H}$ oagland's solution) arranged in a randomized block design with fivereplications. Full strength $\mathrm{H}$ oagland's solution contained the following concentration of nutrients: $15 \mu \mathrm{M} \mathrm{N}, 1 \mu \mathrm{M} \mathrm{P}, 6 \mu \mathrm{M} \mathrm{K}, 5 \mu \mathrm{M} \mathrm{Ca}, 2$ $\mu \mathrm{M} \mathrm{M} \mathrm{g,} 46 \mu \mathrm{M} \mathrm{B}, 9 \mu \mathrm{M} \mathrm{M} \mathrm{n,} 0.8 \mu \mathrm{M} Z \mathrm{n}$, $0.5 \mu \mathrm{M} \mathrm{M} \mathrm{o,} \mathrm{and} 0.3 \mu \mathrm{m} \mathrm{Cu}$ (H oagland and Arnon, 1950). The watermelon seedlings were irrigated daily with the nutrient solutions for 3 weeks and transplanted on 28 A pr. 1995, 13 M ay 1997, and 30 Apr. 1998.

Before planting, the Ruston fine sandy loam soil (fine-loamy, siliceous, thermic, Typic Paleudults) was prepared in late A pril by incorporation of $550 \mathrm{lb} /$ acre $\left(617 \mathrm{~kg} \cdot \mathrm{ha}^{-1}\right)$ of $8 \mathrm{~N}$ $10.5 \mathrm{P}-19.9 \mathrm{~K}$. The final beds were formed and white and black polyethylene mulch was laid. The raised beds [ 6 inches $(15 \mathrm{~cm})$ high $\times 18$ inches $(45$ $\mathrm{cm}$ ) wide on $10 \mathrm{ft}(3 \mathrm{~m})$ centers] were irrigated using drip lines underneath the mulch.

The3-week-old watermelon seedlings were transplanted into holes punched in the polyethylene mulch at $3 \mathrm{ft}(0.9 \mathrm{~m})$ in-row spacing. Each transplant received $16 \mathrm{oz}(0.5 \mathrm{~L})$ of $20 \mathrm{~N}-8.7 \mathrm{P}-16.6 \mathrm{~K}$ water soluble fertilizer mixed at a concentration of 200 ppm (mg $\left.\mathrm{L}^{-1}\right)$ nitrogen. Each treatment plot contained six plantsand was replicated five times in a randomized complete block design. Weed control in the row middles was controlled by application of trifluralin, dimethyl tetrachloroterephthalate, paraquat, and hand weeding. Pesticides were applied as needed for control of insects (carbaryl, endosulfan, and esfenvalerate) and gummy stem blight (chlorothalonil, mancozeb, and benomyl).

Following transplanting, the plants were checked daily for flowers and the date of first open staminate and pistillate flower were recorded for each plant. $M$ ature fruit were harvested on 27 J une, 11 July, and 18 J uly 1995; 23, 30 July, and 6 Aug. 1997; and 29 June, 6,13 , and 20 July 1998 . The 
T able 1. D ays to first staminate and pistillate flowers of watermel on transplants as affected by different root cell volumes and fertility during transplant production for 1995 and 1998.

\begin{tabular}{|c|c|c|c|c|}
\hline \multirow[b]{3}{*}{ Effect } & \multicolumn{2}{|c|}{1995} & \multicolumn{2}{|c|}{1998} \\
\hline & \multicolumn{4}{|c|}{$\begin{array}{l}\text { Days to first } \\
\text { flower after } \\
\text { transplanting }\end{array}$} \\
\hline & Staminate & Pistillate & Staminate & Pistillate \\
\hline \multicolumn{5}{|l|}{ Cell volume $\left[\mathrm{inch}^{3}\left(\mathrm{~cm}^{3}\right)\right]$} \\
\hline $1.9(30.7)$ & 25 & 31 & 29 & 34 \\
\hline $4.0(65.5)$ & 23 & 30 & 26 & 32 \\
\hline $9.0(147.5)$ & 21 & 28 & 24 & 31 \\
\hline $21.3(349.6)$ & 18 & 27 & 23 & 29 \\
\hline \multicolumn{5}{|l|}{ Contrasts } \\
\hline Linear & $* * *$ & $* * *$ & $* * *$ & $* * *$ \\
\hline Q uadratic & NS & NS & NS & NS \\
\hline \multicolumn{5}{|l|}{ H oagland's concentration } \\
\hline Water & 23 & 29 & 27 & 32 \\
\hline $25 \%$ strength & 22 & 29 & 25 & 31 \\
\hline $50 \%$ strength & 22 & 28 & 24 & 31 \\
\hline Full strength & 21 & 28 & 25 & 31 \\
\hline \multicolumn{5}{|l|}{ Contrasts } \\
\hline Linear & $* * *$ & $* * *$ & $* *$ & NS \\
\hline Q uadratic & NS & NS & $*$ & NS \\
\hline \multicolumn{5}{|l|}{ I nteraction } \\
\hline Cell volume $\times$ fertility & NS & NS & NS & NS \\
\hline
\end{tabular}

first harvest in 1995 and 1997 and the first two harvests in 1998 were used to determine early yields. All of the harvestsfor each individual year werecombined for the total harvest data. The harvested fruit werecounted, weighed, and the soluble solids determined by use of a hand-held refractometer (model 852057; Fisher, Pittsburgh, $\mathrm{Pa}$.) to evaluate treatment effects on fruit quality. All data were subjected to general linear models procedure of SAS (version 6.07, SAS I nstitute, Cary, N.C.). R egression analysis was used to determine trends of significant main effects.

\section{Results}

TIME OF FLOWERING. I ncreasing cell volume linearly reduced the length of time of appearance of the first staminate and pistillate flowers following transplanting to the field in 1995 and 1998 (T able 1). Increasing nutrition significantly shortened the time of appearance of the first staminate flowers following transplanting to the field in 1995 and 1998 and appearance of pistillate flowers in 1995. Flowering data were not completed in 1997 and are not presented. No significant cell volume $\times$ nutrition interaction was observed for flowering of the watermelon transplants in any year.

Yield (FRUIT NUMBeR). I ncreasing cell volume linearly increased watermelon number per area in 1995 for both early and total harvests (T able 2). E arly yield also linearly increased with higher fertility rates. Early yield was much more affected by cell volume than total yield. $\mathrm{N}$ either cell volume nor fertility rate affected the number of watermelons per area in 1997. Adverse growing conditions and disease

Table 2. $\mathbf{N}$ umber of fruit per acre for early and total harvest of 'J ubilee' watermelon as affected by root cell volumes and fertility during transplant production in 1995, 1997, and 1998.

\begin{tabular}{|c|c|c|c|c|c|c|}
\hline \multirow[b]{3}{*}{ Effect } & \multicolumn{2}{|c|}{1995} & \multicolumn{2}{|c|}{1997} & \multicolumn{2}{|c|}{1998} \\
\hline & \multicolumn{6}{|c|}{$\mathrm{H}$ arvest (no./acre) ${ }^{2}$} \\
\hline & E arly & T otal & E arly & Total & E arly & Total \\
\hline \multicolumn{7}{|l|}{ Cell volume $\left[\mathrm{inch}^{3}\left(\mathrm{~cm}^{3}\right)\right]$} \\
\hline $1.9(30.7)$ & 254 & 653 & 363 & 774 & 459 & 1137 \\
\hline $4.0(65.5)$ & 399 & 895 & 433 & 981 & 726 & 1149 \\
\hline $9.0(147.5)$ & 666 & 956 & 427 & 954 & 920 & 1379 \\
\hline $21.3(349.6)$ & 672 & 895 & 423 & 853 & 944 & 1234 \\
\hline \multicolumn{7}{|l|}{ Contrasts } \\
\hline Linear & $* * *$ & $*$ & NS & NS & $* * *$ & NS \\
\hline Q uadratic & NS & NS & NS & NS & NS & NS \\
\hline \multicolumn{7}{|l|}{ H oagland's concentration } \\
\hline Water & 341 & 690 & 446 & 892 & 702 & 1186 \\
\hline $25 \%$ strength & 460 & 859 & 397 & 892 & 802 & 1210 \\
\hline $50 \%$ strength & 656 & 980 & 399 & 932 & 835 & 1331 \\
\hline Full strength & 535 & 871 & 399 & 826 & 726 & 1174 \\
\hline \multicolumn{7}{|l|}{ Contrasts } \\
\hline Linear & $*$ & NS & NS & NS & NS & NS \\
\hline Q uadratic & NS & NS & NS & NS & NS & NS \\
\hline \multicolumn{7}{|l|}{ Interaction } \\
\hline Cell volume $\times$ fertility & NS & NS & NS & NS & NS & NS \\
\hline
\end{tabular}

z1 fruit/ acre $=2.47$ fruit/ ha.

$\mathrm{Ns}^{* *}, * *, * * * N$ onsignificant or significant at $\mathrm{P} \leq 0.05,0.01$, or 0.001 , respectively. 
pressurereduced watermelonsper area compared with 1995 values. Increasing cell volume linearly increased watermelons per area for early yield in 1998, while total yield was unaffected.

YIELD (CWT PER ACRE). I ncreasing cell volume linearly increased water- melon yield per area in 1995 for both early and total harvest (Table 3). E arly yield linearly increased with higher fertility rates. O ne-half strength $\mathrm{H}$ oagland's solution produced the greatest watermelon yield per area. Cell volume or fertility rate had no significant influence on 1997 yields because of poor growing conditions and severe disease pressure reduced yield. Increasing cell volume linearly increased watermelon yield per area for both early and total harvest in 1998, while no affect due to nutrition

T able 3. Yield of fruit for early and total harvest of 'J ubilee' watermelon as affected by root cell volumes and fertility during transplant production in 1995, 1997, and 1998.

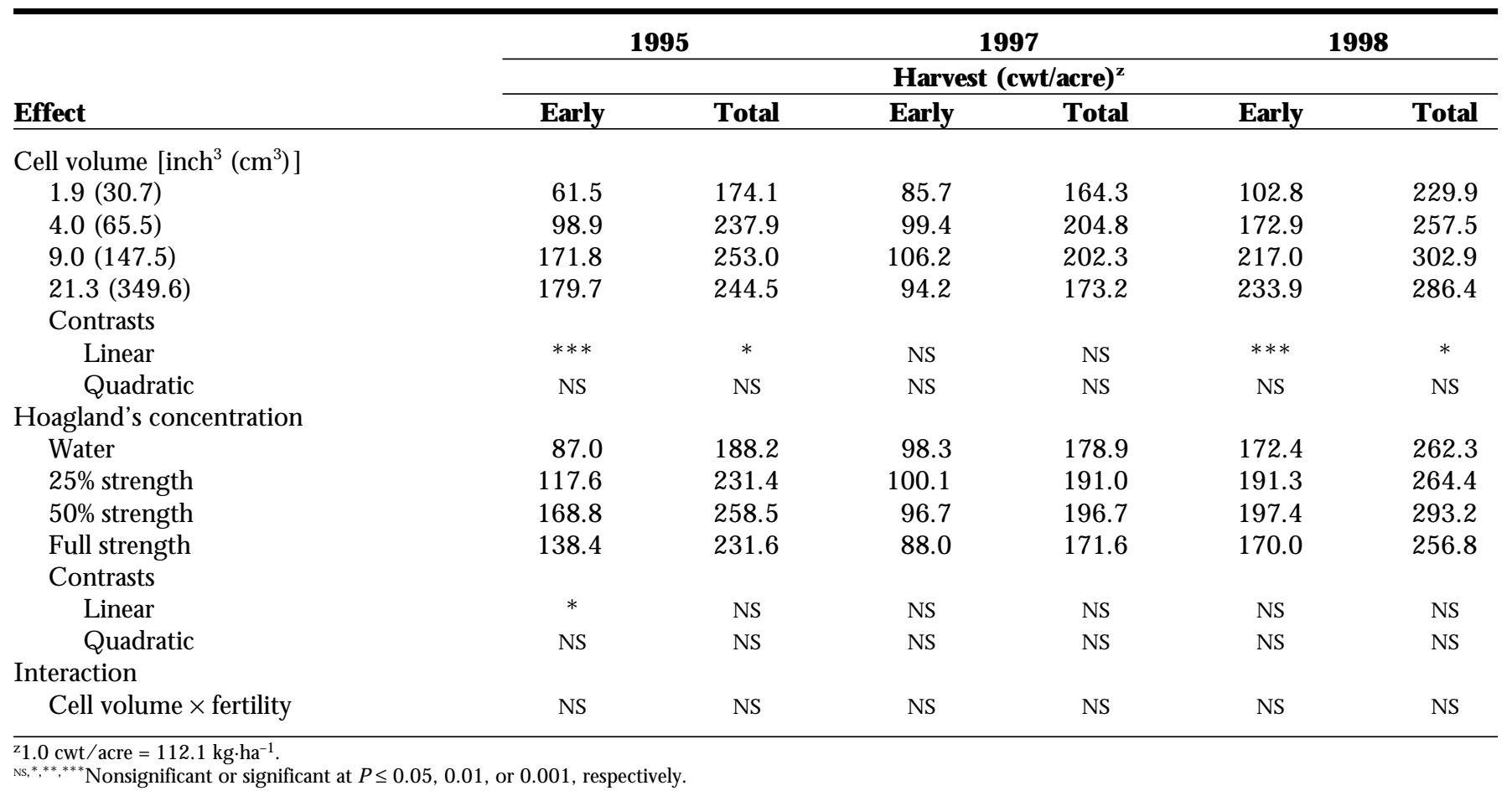

T able 4. A verage fruit weight for early and total harvest of 'Jubilee' watermelon as affected by root cell volumes and fertility during transplant production in 1995, 1997, and 1998.

\begin{tabular}{|c|c|c|c|c|c|c|}
\hline \multirow[b]{2}{*}{ Effect } & \multicolumn{6}{|c|}{ H arvest (lb/fruit) ${ }^{z}$} \\
\hline & E arly & T otal & E arly & T otal & E arly & Total \\
\hline \multicolumn{7}{|l|}{ Cell volume $\left[\mathrm{inch}^{3}\left(\mathrm{~cm}^{3}\right)\right]$} \\
\hline $1.9(30.7)$ & 24.2 & 27.1 & 23.6 & 21.4 & 22.6 & 20.6 \\
\hline $4.0(65.5)$ & 24.6 & 26.5 & 21.5 & 20.2 & 24.2 & 22.3 \\
\hline \multicolumn{7}{|l|}{ Contrasts } \\
\hline Linear & $* * *$ & NS & NS & NS & $*$ & $* *$ \\
\hline Quadratic & NS & NS & NS & NS & NS & NS \\
\hline \multicolumn{7}{|l|}{ H oagland's concentration } \\
\hline Water & 25.4 & 27.5 & 22.6 & 19.8 & 24.9 & 22.5 \\
\hline $25 \%$ strength & 25.0 & 26.9 & 23.9 & 21.8 & 24.1 & 21.7 \\
\hline Linear & NS & NS & NS & NS & NS & NS \\
\hline Quadratic & NS & NS & NS & NS & NS & NS \\
\hline \multicolumn{7}{|l|}{ Interaction } \\
\hline Cell volume $\times$ fertility & $* *$ & NS & NS & NS & NS & NS \\
\hline
\end{tabular}


treatments were detected.

Average fruit weight. The average weight of early harvested fruit was significantly increased as cell volume increased, but this did not hold true for the total harvest datain 1995 (T able 4). Although PNC had no influence on average fruit weight in 1995, there was a significant interaction between cell volume and nutrition on the average fruit weight of early harvested melons. Cell volume or fertility rate had no significant influence on watermel on fruit weight measured in 1997. Although not significant, the smallest cell volume tended to produced the least number of watermelons per area but the largest average melon weight. The average weight of harvested fruit was significantly increased as cell volume increased for both the early and total harvest data in 1998. N utritional conditioning had no statistically measurable role in fruit size regardless of growing year.

FruIT Soluble solids. Soluble solids concentration linearly increased with increasing cell volume for early and total harvests in 1995 (Table 5). Fertility had no significant effect on the concentration of soluble solids in 1995, but did linearly increase the soluble solids concentration of early harvested watermelons in 1997. Soluble solids were not affected by cell volume or transplant PN C in 1998.
For each year, no significant interactions occurred between cell size and fertility for fruit soluble solids data.

\section{Discussion}

The decreases in time to flowering with respect to cell size and nutritional conditioning agree with other reportson watermelon transplant production (Liu and Latimer, 1995; Schultheis and Dufault, 1994). The larger cell volume transplants became established more quickly and vined sooner than transplants produced in smaller cell volume trays, while the nutritional conditioning was variable in plant response with the smaller cells being the most affected. $\mathrm{H}$ all (1989) also noted that the rate of vine growth was greater in plants grown in larger than smaller onesonce transplanted to the field. Transplants with relatively large root systems generally suffer less postplant shock and thus come into production earlier than plants with small root systems (Weston and Zandstra, 1986).

$M$ any morphological and physiological responses of plants to varying container sizes and root restriction conditions have been reported. $\mathrm{H}$ owever, of most concern to the end user of the transplant is the postplant performance of the seedling. O f particular concern is crop yield resulting from transplants grown in different con- tainer sizes ( $\mathrm{N} \mathrm{eSmith}$ and Duval, 1998). In our studies, varying transplant container size when growing watermelon has shown mixed results for early and total yields. The increases in total number of watermelons per area in 1995 and the total yield per area in response to increasing cell volume in 1995 and 1998 for this study agree with research by Liu and Latimer (1995). They reported the number of watermelons and the total yield of 'Starbrite' watermelons significantly increased as cell volume increased, but there was no significant effect on fruit weight. H all (1989) reported that 'C harleston Gray' watermelon plants grown in 2.4-inch ${ }^{3}\left(40-\mathrm{cm}^{3}\right)$ cells produced greater lateand total yieldsthan those grown in 1.2-inch ${ }^{3}\left(19-\mathrm{cm}^{3}\right)$ cells, but 'Crimson Sweet' yield was not affected by cell size. Vavrina et al. (1993) also reported no significant differencesin total yield of ' $C$ harleston Gray' transplants produced in 1.2-, 1.9-, and 4.0-inch ${ }^{3}$ (19-, 30.7-, and $\left.65.5-\mathrm{cm}^{3}\right)$ cells. The data from this study and previous research suggest that an environmental interaction as well as differences in cultivar response may be influencing watermelon yield.

Commercial production of transplants needs to be as pragmatic as possible. Complex nutritional practices are only justified if the subsequent transplants perform better in

T able 5. F ruit soluble solids concentration of 'J ubilee' watermelon as affected by root cell volumes and fertility during transplant production in 1995, 1997, and 1998.

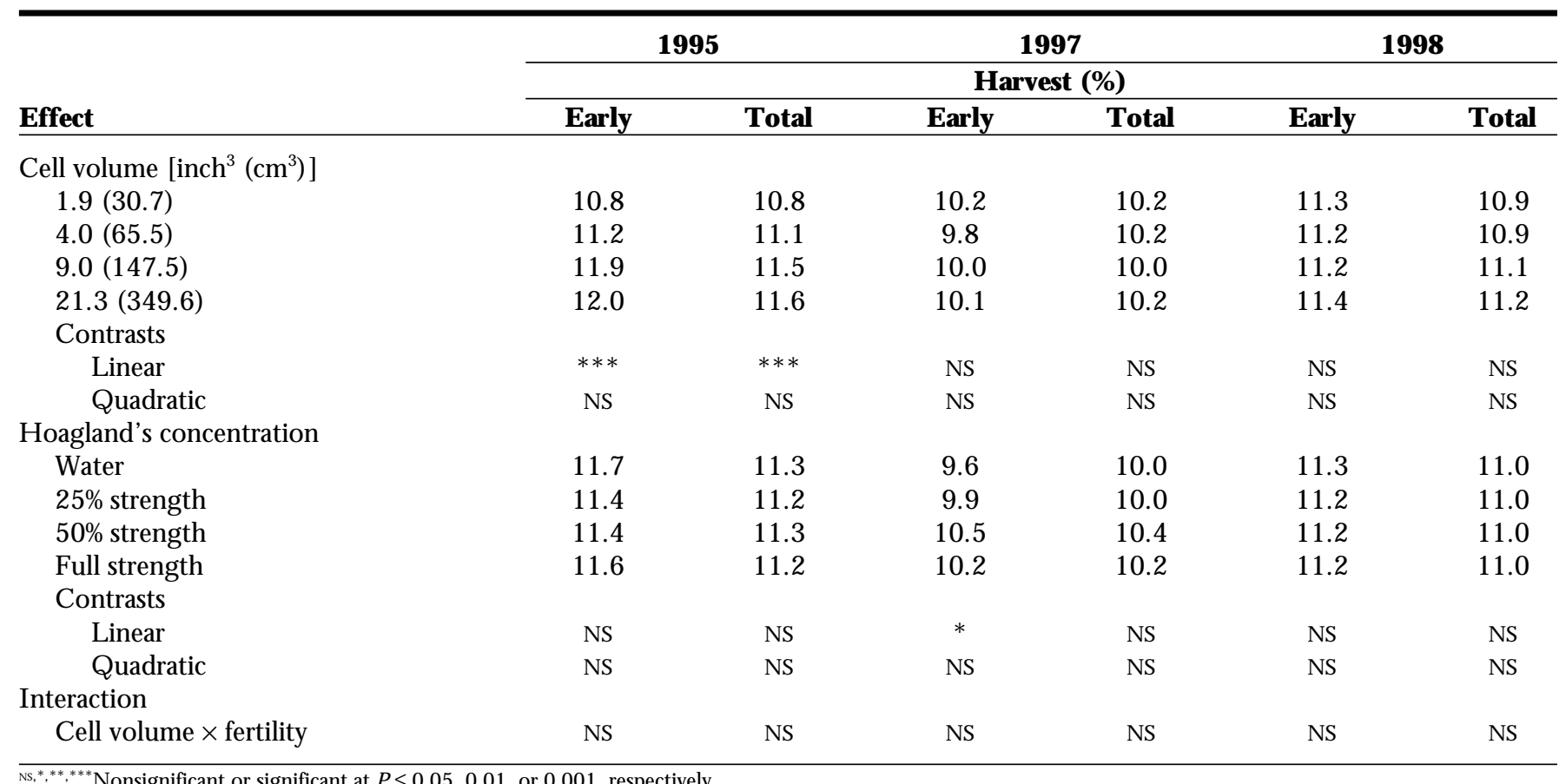


the field. Performance includes improvements in stand establishment coupled with enhancements in one or more attributes of earliness, uniform maturity, yield quantity and quality, and postharvest holding superiority (D ufault, 1998). In this study, PN C significantly increased the fruit number and tonnage for early harvests in 1995 and soluble solids in early harvested fruit in 1997 but had no significant effect on total 'Jubilee' watermelon production or fruit quality in Louisiana for 1995, 1997, or 1998. This agrees with reports by Schultheis and Dufault (1994) on watermelons grown in North Carolina and South Carolina. They found total yield of 'Q ueen of $\mathrm{H}$ earts' and 'C rimson Sweet' watermelons were unaffected by PN C treatments of 25 to $225 \mathrm{ppm}\left(\mathrm{mg} \cdot \mathrm{L}^{-1}\right)$ nitrogen and 5 to $45 \mathrm{ppm}$ phosphorus. Thelimited research of PN C on watermelon suggests that there is no significant advantage of using low or high rates of nutrients in transplant production in regard to the total production of watermelons.

This study provides supporting evidence that container size is an important consideration for watermelon transplant consumers who seek to optimize early production and maximize total production. Whiletransplant producers opt for smaller cell volumes to reduce transplant cost, a median must befound to providetheleast expensive transplant while not sacrificing yields and profits for the vegetable grower.

\section{Literature cited}

Adler, P.R., R.J. D ufault, and L. Waters, Jr. 1984. I nfluence of nitrogen, phosphorus and potassium on asparagus transplant quality. H ortScience 19(4):565-566.

Dufault, R.J. 1986. Influence of nutritional conditioning on muskmelon transplant quality and early yield. J. Amer. Soc. H ort. Sci. 111(5):698-703.

D ufault, R.J. 1998. Vegetable transplant nutrition. H ortT echnology 8(4):515-523.

D ufault, R.J. and L. Waters, J r. 1985. Container sizeinfluencesbroccoli and cauliflower transplant growth but not yield. H ortScience 20(4):682-684.

Giacchetti, N. 1997. Watermelon transplants are top seeded. Amer. Veg. Grow. 45(1):D-E .

H all, M.R. 1989. Cell size of seedling containers influences early vine growth and yield of transplanted watermelon. H ortScience 24(5):771-773.

H oagland, D.R. and D.I. Arnon. 1950. The water culture method for growing plants without soil. Calif. Agr. Expt. Sta. Circ. 347.

I vanhoff, S.S., R.C. Albritton, C.L. Blount, and B.E. Waggoner. 1960. Watermelon transplants for healthier, earlier, and more profitable crops. M iss. Agr. Expt. Sta. Bul. 588.

Liu, A. and J.G. Latimer. 1995. Root cell volume in the planter flat affects watermelon seedling development and fruit yield. H ortScience 30(2):242-246.

M arsh, D.B. and K.B. Paul. 1988. Influence of container type and cell size on cabbage transplant development and field performance. H ortScience 23:310-311.

Melton, R.R. and R.J. Dufault. 1991. Tomato seedling growth, earliness, yield, and quality following pretransplant nutritional conditioning and low temperatures. J. Amer. Soc. H ort. Sci. 116(3):421-425.

NeSmith, D.S. and J.R. D uval. 1998. The effect of container size. H ortT echnology 8(4):495-498.

N ettles, V.F. 1963. Planting and mulching studies with cucurbits. Proc. Fla. State H ort. Soc. 76:178-182.

N orton, J.D . 1968. Effects of field seeding and transplanting on earliness, quality, and yield of cantaloupe varieties. $\mathrm{H}$ ortScience 3(3):175-177.

Schultheis, J.R. and R.J. D ufault. 1994. Watermelon seedling growth, fruit yield, and quality following pretransplant nutritional conditioning. HortScience 29(11):1264-1268.

Vavrina, C.S. 1997. Bigger is actually better. Amer. Veg. Grow. 45(4):36-37.

Vavrina, C.S., S. Olson, and J.A. Cornell. 1993. Watermelon transplant age: I nfluenceon fruityield. H ortScience 28(8):789790.

Weston, L.A. and B.H. Zandstra. 1986. Effect of root container sizeand location of production on growth and yield of tomato transplants. J. Amer. Soc. H ort. Sci. 111(4):498-501.

Weston, L.A. and B.H. Zandstra. 1989. Transplant age and $\mathrm{N}$ and $\mathrm{P}$ nutrition effects on growth and yield of tomatoes. $\mathrm{H}$ ortScience 24:88-90. 